\title{
Pore structural characteristics and methane adsorption capacity of transitional shale of different depositional and burial processes: a case study of shale from Taiyuan formation of the Southern North China basin
}

\author{
Qiuchen $\mathrm{Xu}^{1} \cdot$ Haizhou Wang ${ }^{2,3} \cdot$ Ruiliang Guo $^{4} \oplus \cdot$ Peng Liu $^{5} \cdot$ Dishi Shi ${ }^{1} \cdot$ Enran Liu ${ }^{1} \cdot$ Yang Zhang ${ }^{2,3} \cdot$ Keyi Wei $^{2,3}$
}

Received: 19 July 2021 / Accepted: 26 October 2021 / Published online: 8 November 2021

(c) The Author(s) 2021

\begin{abstract}
Pore structural characteristics and methane adsorption capacity are two significant aspects affecting shale gas potential, but the impact of deposition and burial processes on these two aspects is not clear. Hence, the shale samples of Taiyuan Formation deposited continuously and experienced multi-stage tectonic uplift in Fuyang-Bozhou area of Southern North China Basin were collected in this study. Based on the total organic carbon content analysis, mineral composition determination, lowpressure $\mathrm{CO}_{2}$ and $\mathrm{N}_{2}$ adsorption, high-pressure methane adsorption and argon ion polishing-field emission scanning electron microscope observation. The impact of depositional and burial processes variation on shale reservoir physical properties and adsorption performance is studied. The results display that the pore types of shale samples which were continues deposited and experienced multi-stage tectonic uplift have no obvious differences, while the pore volume as well as specific surface area (SSA) of micropores and mesopores of shale samples under multi-stage tectonic uplift are larger significantly. Meanwhile, the roughness of shale pores increases also. The decrease of loading pressure caused by multi-stage tectonic uplift may be the main factor for the pore structure changes of shale sample. Compared with the continuous deposited samples, the shale samples under multi-stage tectonic uplift have stronger methane adsorption capacity, which is relevant to the greater SSA of micropores as well as mesopores. This study provides an example and new revelation for the influence of depositional and burial processes on shale pore structure and methane adsorption capacity.
\end{abstract}

Keywords Shale gas · Pore structure $\cdot$ Southern North China Basin $\cdot$ Depositional and burial processes $\cdot$ Methane adsorption capacity

Haizhou Wang

haizhou.wang@cup.edu.cn

$\triangle$ Ruiliang Guo

guoruiliang1991@163.com

1 Oil and Gas Survey, China Geological Survey, Beijing 100083, China

2 State Key Laboratory of Petroleum Resources and Prospecting, College of Geosciences, China University of Petroleum (Beijing), Beijing 102249, China

3 College of Geosciences, China University of Petroleum (Beijing), Beijing 102249, China

4 School of Earth Sciences and Engineering, Shaanxi Key Laboratory of Petroleum Accumulation Geology, Xi' an Shiyou University, Xi' an 710065, China

5 College of Safety Science and Engineering, Xi' an University of Science and Technology, Xi' an, Shanxi 710054, China

\section{Introduction}

Shale is an important sedimentary rock in the petroleum system in terms of exploration as unconventional reservoir, source rock and wellbore stability of drilled holes (Radwan 2021; Radwan et al. 2020, 2019). Over recent years, shale gas acts as an important unconventional natural gas resources worldwide and gains significant breakthroughs in U.S. and China (Zou et al. 2016). Among the shale gas producing area in China, Wufeng-Longmaxi Formation was considered as the most successful shale gas prospecting and production practice (Hu et al. 2018; Liang et al. 2017). Meanwhile, some breakthroughs has also been achieved in Upper Triassic Yanchang continental shale system of Ordos Basin (Guo et al. 2014; Wang et al. 2020). Basically, shale gas is featured by self-generation and self-storage (Zou et al. 
2010). The hydrocarbon gases in shale can exist as different states, including dissolved state in liquid hydrocarbon, adsorbed state in micropores and mesopores as well as free state in macropores (Li et al. 2018; Liu et al. 2020a; Martini et al. 1998). The adsorbed gas proportion of shale gas is generally between 20 and $85 \%$, indicating that the adsorbed state of shale gas is the dominant factor affecting shale gas potential.

During the evolution of petroliferous basin, differential uplift that occurred during the rifting period can lead to varying deposition burial processes of shale in a same sedimentary period (Zhang et al. 2020a). Shale with different deposition burial processes is characterized by different maturity level, total organic carbon (TOC) content and burial depth, may revealing a different physical property parameters (e.g., porosity, permeability and pore structure characteristics) of shale (Zhang et al. 2020b). However, previous studies mainly focused on the influence of thermal evolution process, soluble organic matter and other factors on shale pore structure. Only a few studies focus on the pore network and methane adsorption characteristics of shale with different deposition burial processes. Chen et al. (2007) carried out a simulation experiment on coal, which confirmed that the uplift events can reduced the formation and overburden pressure, resulting in the opening of cleavage fractures, and further leading the increase of fracture permeability and significantly affected the coal reservoir physical properties. Wang et al. (2018) studied the impact of differential uplift on Chang 7 shale reservoir physical properties in Ordos Basin, and it is concluded that the physical property of samples with stronger uplift are better than that of relatively stable tectonic condition.

The shale gas prospecting and development practice in the Southern North China Basin (SNCB) lately shows that Taiyuan Formation is a set of coal strata formed in marineterrestrial transitional environment. The shale in Taiyuan Formation is characterized by wide distribution, giant accumulated thickness and high organic matter abundance. It displays well shale gas production and is a potential shale gas prospecting area. SNCB is a Mesozoic-Cenozoic superimposed basin developed on the basis of North China platform (Liu et al. 2019). It has generally experienced the development stage of intracontinental extensional rift basins from late Jurassic to early Cretaceous and Paleogene, resulting in a wide range of different uplift processes in the basin (Meng et al. 2019). Therefore, though widely distributed, shale of Taiyuan Formation has different burial processes at the basin scale. Furthermore, it is not clear whether the pore structure characteristics and methane adsorption capacity of Taiyuan Formation shale with different burial evolution are affected by depositional and burial processes. The adsorbing capacity of methane can reflect the shale gas potential and is considered as a direct parameter for evaluation favorable prospecting area of shale gas (Tan et al. 2014). Meanwhile, pore structural features of shale may act as the leading factor influencing the methane adsorption capacity (Cai et al. 2013). Hence, we can understand the pore evolution process of shale and its response to burial history by studying the differences in pore structure characteristics and methane adsorption capacity between Taiyuan shales with different burial history in SNCB, and judge the differences in methane adsorption properties, so as to provide a theoretical basis for the selection of shale gas sweet spot.

Therefore, Taiyuan shale with varying depositional and burial processes, including samples deposited continuously and experienced multi-stage tectonic uplift in FuyangBozhou area of the SNCB, were collected in this study. The TOC content determination, low-pressure $\mathrm{CO}_{2}$ and $\mathrm{N}_{2}$ adsorption, mineral components analysis, high-pressure methane adsorption experiment and argon ion polishing FESEM observing were carried out. Based on this, the physical properties and methane adsorption capacity of the Taiyuan shale with varying depositional and burial processes were compared, the impact and mechanism of depositional and burial processes on shale reservoir physical properties and adsorption performance are studied and discussed.

\section{Geological settings}

As a Meso-Cenozoic superimposed basin, the SNCB is located between the North China plate in the North and the Dabie orogenic belt in the South (Li et al. 2021). The basin has been experienced multi-stage tectonic movements since the late Paleozoic and generally can be divided into flowing tectonic units, including Kaifeng depression, Taikang uplift, Zhoukou depression, Bengbu uplift, Huaibei uplift and Xinyang-Hefei depression (Li et al. 2021).

The faults strike in the basin is consistent with that of the Tanlu fault and the Qinling-Dabie orogenic belt and are mainly NNE and NWW trending (Liu et al. 2019). There are numerous Meso-Cenozoic depressions in the basin, which are superimposed by several basin prototypes on the basis of nearly EW basement structure (Meng et al. 2019). The overall extension direction is nearly EW, which is parallel to the Qinling-Dabie orogenic belt.

The Carboniferous-Permian shales in the SNCB are chiefly developed in Benxi, Taiyuan, Shanxi and Shihezi Formation, which is featured by wide distribution, large thickness and organic matter with mature to over mature maturity (Li et al. 2021). Previous studies reveal that the late Paleozoic North China paleocontinent began to intrude from South to North and from Northeast to Southwest in the Late Carboniferous, forming the North China plate, and developed the Late Carboniferous Permian marine-continental facies shale (Meng et al. 2019). The shale mainly distributed 
in the North of Jieshou-Taihe fault, including Yanji, Luyi, Niqiuji, Santaji depressions and Gucheng low uplift and is contiguous and thinned from North to South.

\section{Samples and experiments}

\section{Sample collection}

Three typical shale samples from Well BC1 of Taiyuan Formation were collected, Well BC1 was a single borehole which is located in the Wanglou slope of Yanji Depression in the SNCB (Fig. 2). In general, Yanji sag is located in the Northern Fuyang area, the Eastern edge of Taikang uplift, Yanji fault in the West and Gucheng fault in the South (Figs. 1 and 2). It is a dustpan like Mesozoic to Cenozoic sag faulted in the West and overtopped in the East. The sedimentary structural evolution is continuous subsidence, that

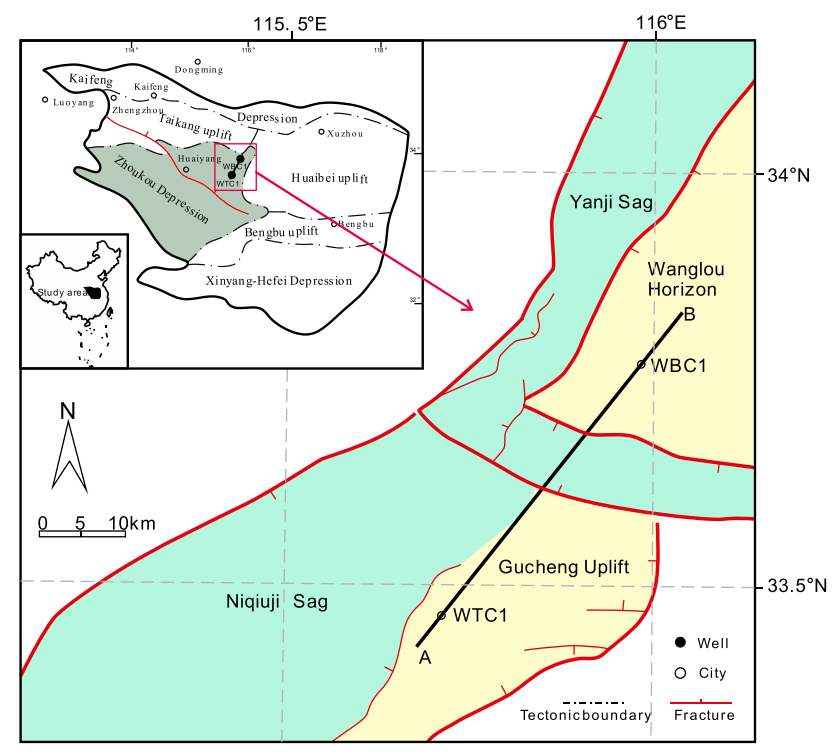

Fig. 1 Division of structural units and location of study area in Southern North China Basin is, after uplift and erosion of Indosinian movement, though it was affected by uplift at the end of Mesozoic, it was in continuous subsidence in Mesozoic to Cenozoic basically (Meng et al. 2019). The deep strata in the depression are well preserved, and the Paleogene and Cretaceous strata are missing in the Wanglou slope. The depth of three shale samples is between $2713.79 \mathrm{~m}$ and $2718.52 \mathrm{~m}$.

Six shale samples from Well TC1 of Taiyuan Formation were collected. Well TC1 is located in the Gucheng lower uplift in the SNCB (Figs. 1 and 2). Gucheng lower uplift is a NW distribution Paleozoic uplift clamped by three extensional faults. Besides small subsidence in Mesozoic and Cenozoic after Indosinian uplift, the sedimentary structural evolution is generally featured by uplift. The CarboniferousPermian strata in Gucheng uplift are well preserved, with a buried depth of 700-1800 m, generally $1100-1500 \mathrm{~m}$, stable distribution and undeveloped faults. Shale and mudstone are widely distributed and relatively stable in thickness. The depth of the six collected shale samples ranges from 1501.50 to $1533.00 \mathrm{~m}$.

\section{Analyzes}

\section{(1) TOC contents determination}

The TOC contents were determined by a LECO CS-230 Carbon-Sulfur instrument. In this study, the process of the measurement of TOC contents was followed by National standard of P.R. China (GB/T 19,145-2003). At first, the samples were crushed to $>100$ mesh. Then, excessive hydrochloric acid was added to the shale samples slowly and heated for about $2 \mathrm{~h}$ with temperature ranging from 60 to $80{ }^{\circ} \mathrm{C}$, this process can ensure the inorganic carbon be removed completely. Then, the sample was put in the porcelain crucible which lay on a nutsch filter and water-washed until neutral. Finally, the sample was dried with temperature ranging from 60 to $80^{\circ} \mathrm{C}$, then using the LECO carbon and sulfur measuring instrument determine the TOC value of the residual samples. The TOC contents were reported as $\mathrm{wt} \%$.
Fig. 2 Structural stratigraphic profile of sampling well location

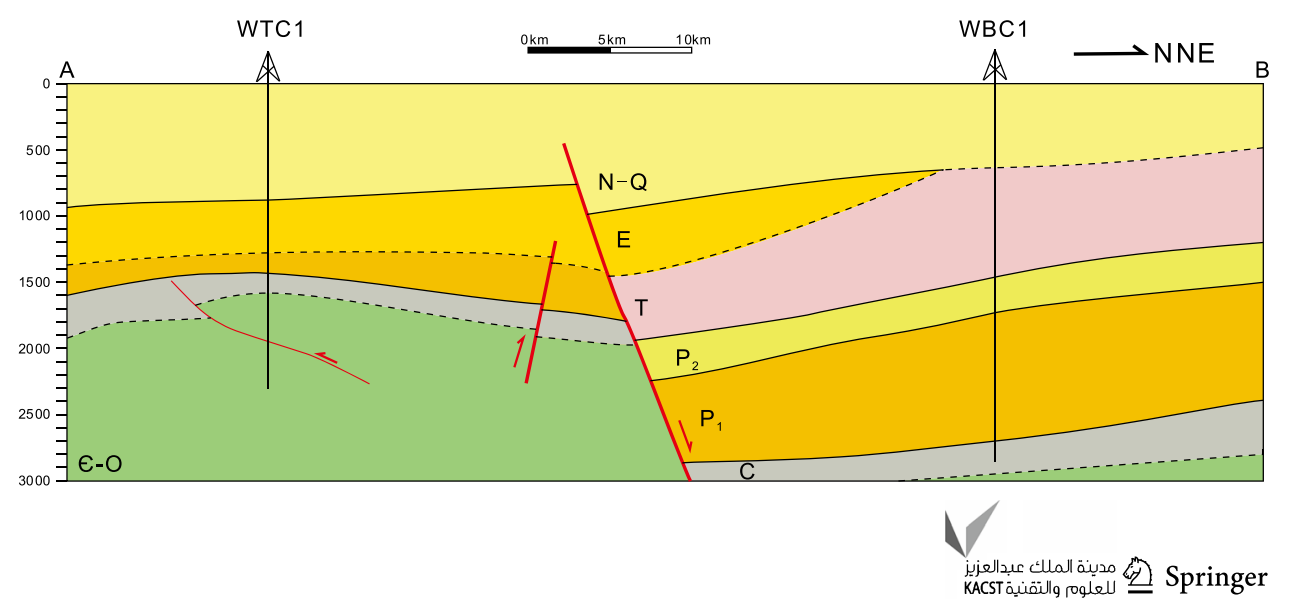




\section{(2) X-ray diffraction analysis of mineral components}

The mineral components and contents of shale samples were measured by a Bruker D8 advance X-ray diffractometer with a $\mathrm{Cu}$ tube. Before the experiment, the samples were smashed to $>200$ mesh. The measuring condition is: temperature of $24{ }^{\circ} \mathrm{C}$ and humidity of $35 \%$; the tube voltage and electric current are less than $40 \mathrm{kV}$ and $40 \mathrm{mV}$, respectively; the scan ranges from 0 to $140^{\circ}$ with a rate of $2^{\circ} / \mathrm{min}$ and step size of $0.02^{\circ}$.

\section{(3) Low pressure $\mathrm{N}_{2}$ adsorption analysis}

Low pressure $\mathrm{N}_{2}$ adsorption experiments of the samples were conducted to acquire the characteristics of the specific surface area (SSA), pore volume (PV) and pore width (PW) distribution of the pore with width more than $1.73 \mathrm{~nm}$. The experiments were finished by an ASAP 2020 surface area analyzer (Micromeritics, USA). Firstly, the samples were smashed to 60 to 80 mesh, and the powders were placed into the sample tube at $120^{\circ} \mathrm{C}$ for about $10 \mathrm{~h}$ to remove the adsorbed gas on the samples surface. Then, the adsorption analysis was performed using $\mathrm{N}_{2}$ as the adsorbed gas with temperature at $-196{ }^{\circ} \mathrm{C}$. During the adsorption experiment of $\mathrm{N}_{2}$, quantitative gas was injected into the manifold, and the system pressure was measured by the pressure sensor. Then, after the pressure was balanced, open the sample valve to diffuse the gas into pores. A corresponding equilibrium point can be obtained as the pressure reaches equilibrium. Then, the adsorption isotherm can be obtained by repeating above process. In this study, the partial pressure $\left(\mathrm{P} / \mathrm{P}_{0}\right)$ of $\mathrm{N}_{2}$ is between 0 and 1 . The adsorption amounts of $\mathrm{N}_{2}$ are a function of the $\mathrm{P} / \mathrm{P}_{0}$. In the $\mathrm{P} / \mathrm{P}_{0}$ range of $0.0009-0.995$, the pressure increased to the saturated vapor pressure of $\mathrm{N}_{2}$ firstly and then reduce the pressure until the nitrogen is completely precipitated to determine the nitrogen adsorption/desorption curve, which is the only experimental measured data. On this basis, using the model of brunauere Emmet Teller (BET) and Barrett Johner halenda (BJH) to acquire the characteristics of SSA, PV as well as PW distribution.

\section{(4) Low pressure $\mathrm{CO}_{2}$ adsorption analysis}

Low pressure $\mathrm{CO}_{2}$ adsorption experiments were conducted to acquire the characteristics of the SSA, PV and PW distribution of the pore with width less than $1.40 \mathrm{~nm}$. The experiments were finished by an ASAP 2020 surface area analyzer (Micromeritics, USA). Firstly, the samples were smashed to about 70 mesh, then the powders were placed into the sample tube at $120^{\circ} \mathrm{C}$ for about $10 \mathrm{~h}$ to remove the surface adsorbed gas. Next, the adsorption analysis was performed using $\mathrm{CO}_{2}$ as the adsorbed gas with temperature at $0{ }^{\circ} \mathrm{C}$. During the adsorption experiment of $\mathrm{CO}_{2}$, quantitative gas was injected into the manifold, and the system pressure was measured by the pressure sensor. Then, after the pressure was balanced, open the sample valve to diffuse the gas into pores. A corresponding equilibrium point can be obtained as the pressure reaches equilibrium. Then, the adsorption isotherm can be obtained by repeating above process. In this study, the partial pressure $(\mathrm{P} /$ $\mathrm{P}_{0}$ ) of $\mathrm{CO}_{2}$ is between 0 and 0.03 , and the adsorption curve of $\mathrm{CO}_{2}$ can be obtained. On this basis, the SSA, PV and PW are calculated by the model of Dubinin-Radushkevich (DR) and Density Functional Theory (DFT).

\section{(5) FE-SEM Observation}

Nine shale samples were selected to research the microscopic visualization features of pore system and minerals identification. In the Donghua University of Technology, the FE-SEM images of pore morphology visualization were acquired by using a FEI Nova Nano SEM 450. The sample pretreatment process is as follows: the samples were burnished with sandpaper and purged by argon ion beam with Gatan 685 PECS II instrument to achieve flat high resolution observation. Each sample was polished for $2.5 \mathrm{~h}$ at the current of $5.00 \mu \mathrm{A}$ and the acceleration voltage of $6.00 \mathrm{keV}$. In order to prevent the sample from being damaged by discharge and electron beam during the observation, a relatively low acceleration voltage was used, and observation multiples range from $500 \times$ to $10,000 \times$. Meanwhile, using energy dispersive X-ray spectrometer (EDS) to identify the mineral type of specific detrital grains.

\section{(6) High pressure methane adsorption analysis}

One sample from Well TC1 and two samples from Well $\mathrm{BC} 1$ were selected to conduct the high-pressure methane adsorption determination, and the experiment was conducted on a ISOSORP-HP Static II (Rubotherm GmbH, Germany) magnetic suspension balance. The sample in this study was firstly crashed to 60-80 mesh and transferred to the container, pumped to below $10^{-6} \mathrm{MPa}$ and kept at $105^{\circ} \mathrm{C}$ for $4 \mathrm{~h}$ to remove the absorbed materials. After finishing the buoyancy measurement, the sorption measurement can be conducted through increasing the pressure from 0 to $30 \mathrm{MPa}$ at $60{ }^{\circ} \mathrm{C}$, and each specified pressure is balanced for about $2 \mathrm{~h}$. Hence, the curve of $\Delta \mathrm{M} / \Delta \mathrm{P}$ for same temperature can be ultimately acquired through buoyancy calibration.

\section{Results and discussions}

\section{TOC contents and mineral composition characteristics}

Table 1 shows the TOC contents and mineral components of the shale. The TOC contents of samples in Well TC1 are 
between 1.06 and $2.02 \%$, with an average of $1.56 \%$. The TOC contents of samples in Well $\mathrm{BC} 1$ range from 1.23 to $1.89 \%$, with an average of $1.46 \%$. Generally, the clay minerals and quartz are the main components of samples. The quartz contents of samples in Well TC1 range from 24 to $62 \%$ (average $=44 \%$ ). The average contents of quartz of samples in Well $\mathrm{BC} 1$ are $33 \%$. While the average contents of clay minerals of samples in Well TC1 and BC1 are 31 and $20 \%$, respectively. Moreover, the content of muscovite in shale from Well $\mathrm{BC} 1$ is relatively high. However, the content of muscovite in three samples of Well TC1 is relatively low. Generally, the results show that no obvious difference in the TOC contents and mineral composition among two wells can be observed.

\section{Microscopic features of pore system}

Based on the shale pore types classification from Loucks et al. 2012, the microscopic pore types of shale samples in Wells TC1 and BC1 include interparticle pore (Inter-Pore), intraparticle pore (Intra-Pore), micro fracture and organic pore. Specifically, Inter-Pores are chiefly narrow and polygonal shaped, in which a small amount of detrital or clay mineral are filled (Fig. 3e). Intra-Pores are mainly disordered inter-crystalline pores associated with clay matrix (Fig. 3c, $\mathrm{d}$ and $\mathrm{f}$ ), in which Intra-Pores within clay are mostly hosted by I/S mixed layer aggregates and constitute the mainstay of micro-pores. Long micro fractures that cut through the grains are quite developed and mainly distributed in shale samples of TC1 (Fig. 3a, b), together with inter-crystalline pores comprised the most common pores of the shale samples. In addition, organic matter pores (OM-Pores) basically undeveloped both in the in situ primary $\mathrm{OM}$ and migrated OM bands (Fig. 3h, i), only a few shrinkage pores at the edge of OM can be seen in TC1 shale samples (Fig. 3g). Massive and pyrite framboids and aggregates can be seen in all shale samples (Fig. 3g, h, i), but inter-crystalline pores within pyrite are undeveloped. In general, micro fractures and clay mineral inter-crystalline pores constitute the main pore space of all shale samples. Compared with $\mathrm{BC} 1$ samples, shale samples of TC1 are more abundant in micro fractures and shrinkage pores of $\mathrm{OM}$, so are better in pore space and reservoir condition.

\section{Comparison of pore structure and methane adsorption capacity in shale with different deposition burial processes}

\section{Types of adsorption-desorption isotherms and Hysteresis Loops}

The quantity adsorbed $\mathrm{N}_{2}$ at different relative pressure (P/Po) for adsorption and desorption processes are the only directly measured data in the low pressure $\mathrm{N}_{2}$ adsorption determination. Figures 4 and 5 present the adsorption-desorption isotherms of $\mathrm{N}_{2}$ for the shale samples from Well TC1 and $\mathrm{BC} 1$, respectively. Based on the $\mathrm{N}_{2}$ adsorption-desorption isotherm curve classification of BDDT (brunauer-demingdeming-teller) (Brunauer et al. 1940), the low pressure $\mathrm{N}_{2}$ isotherms are belonged to the type II, indicating that reversible multi-layer adsorption can be occurred in the Taiyuan shale from wells $\mathrm{TC} 1$ and $\mathrm{BC} 1$. In addition, the hysteresis Loops can be observed in all the samples from shale of the wells TC1 and BC1. Generally, the hysteresis Loops were generated by capillary condensation, which makes $\mathrm{N}_{2}$ molecules condense and fill the meso-porous pores at a relative low pressure, leading to the in coincide of the adsorption and desorption isotherms. In this study, the hysteresis Loops can be considered $\mathrm{H}_{3}$ based on the IUPAC (International Union of the Pure and Applied Chemistry) classification criteria of the adsorption hysteresis (Sing 1982). It is revealed that the pore morphology of both samples from wells TC1 and BC1 are chiefly wedge-shaped, which was formed by the loose stacking of flaky particles. Hence, the experimental results

Table 1 TOC contents and mineral composition of Taiyuan shale in the SNCB

\begin{tabular}{|c|c|c|c|c|c|c|c|c|c|c|}
\hline Area & Sample No. & $\begin{array}{l}\text { Depth } \\
(\mathrm{m})\end{array}$ & $\begin{array}{l}\text { TOC } \\
(\%)\end{array}$ & Quartz (\%) & Feldspar (\%) & Muscovite (\%) & Clay (\%) & Graphite (\%) & Pyrite (\%) & Dolomite (\%) \\
\hline \multirow[t]{6}{*}{ WellTC1 } & TC1-1 & 1501.50 & 2.02 & 34 & 2 & 45 & 19 & - & - & - \\
\hline & TC1-2 & 1502.00 & 1.48 & 62 & 1 & 6 & 27 & - & 4 & - \\
\hline & TC1-8 & 1508.50 & 1.69 & 49 & 2 & 6 & 42 & - & 1 & - \\
\hline & TC1-4-1 & 1523.00 & 1.47 & 24 & 1 & 3 & 40 & - & - & 32 \\
\hline & TC1-9 & 1526.00 & 1.06 & 48 & 3 & 28 & 15 & 4 & - & 2 \\
\hline & TC1-4-2 & 1533.00 & 1.62 & 45 & 2 & 11 & 40 & - & 2 & - \\
\hline \multirow[t]{3}{*}{ WellBC1 } & $\mathrm{BC} 1-\mathrm{N} 155$ & 2713.79 & 1.23 & 34 & 2 & 45 & 19 & - & - & - \\
\hline & BC1-N159 & 2716.74 & 1.26 & 26 & 2 & 52 & 20 & - & - & - \\
\hline & BC1-N161 & 2718.52 & 1.89 & 39 & 2 & 40 & 19 & - & - & - \\
\hline
\end{tabular}

-means no data 


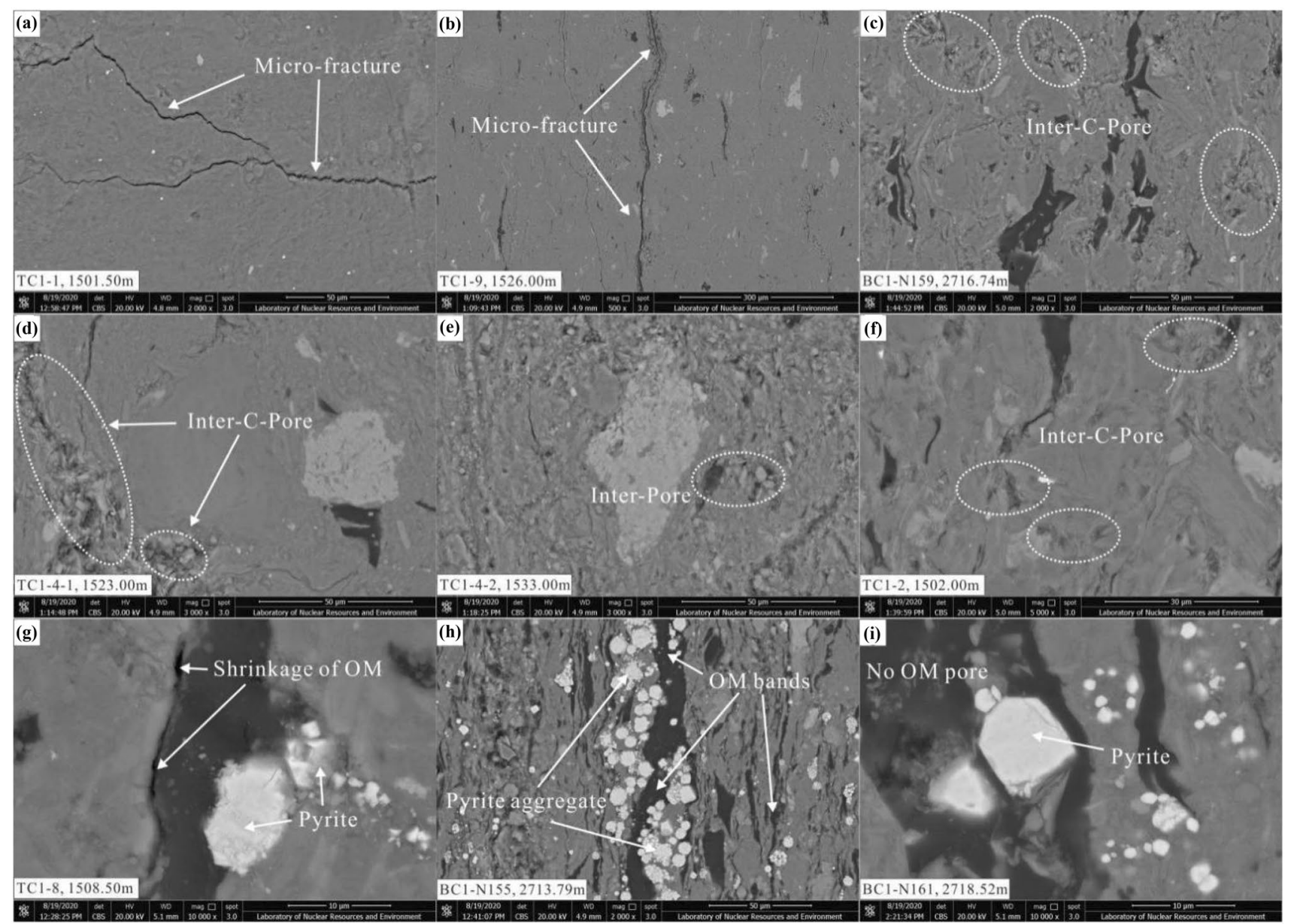

Fig. 3 FE-SEM images displaying pore system microscopic features of the $\mathrm{TC} 1$ and $\mathrm{BC} 1$ shale samples. a long micro fracture cutting through mineral grains; b long micro fracture; c slit-like Intraparticle pore (Intra-Pore) and disordered inter-crystalline pore within clay matrix (Inter-C-Pore); d disordered Inter-C-Pore are well developed; e polygonal interparticle pore (Inter-Pore) are partially filled with

indicate that no obvious different of adsorption-desorption isotherms and Hysteresis Loops can be observed between the samples with varying depositional and burial processes.

\section{Pore width distribution}

Based on the quantity adsorbed $\mathrm{N}_{2}$ and $\mathrm{CO}_{2}$ at different relative pressure $\left(\mathrm{P} / \mathrm{P}_{\mathrm{o}}\right)$, the $\mathrm{PW}$ distribution can be obtained by applying the model of Barrett-Johner-Halenda (BJH) and Density Functional Theory (DFT). Generally, the Low pressure $\mathrm{N}_{2}$ adsorption can obtain pore structure characteristics more than $2 \mathrm{~nm}$. Whereas, the Low-pressure $\mathrm{CO}_{2}$ adsorption analysis can obtain pore structure characteristics less than $2 \mathrm{~nm}$. Hence, the $\mathrm{N}_{2}$ and $\mathrm{CO}_{2}$ adsorption determination were combined to demonstrate the full-scale PW distribution of shale. detrital and clay minerals; f narrow and disorder Inter-C-Pore; $\mathbf{g}$ massive and aggregate pyrite without any pore, as well as shrinkage developed at the organic matter (OM) rim; h OM bands and generous strawberry pyrite aggregates; $\mathbf{i}$ massive and granular pyrite along with OM without any pore developed

Figure 6 presents the relationship of incremental pore area with PW of shale samples in well $\mathrm{TC} 1$ and well $\mathrm{BC} 1$. The results show that the SSA of micropores in well TC1 and $\mathrm{BC} 1$ have the same characteristics. However, the SSA of mesopore and macropore in the two boreholes are obviously different. In general, samples in well TC1 has a greater SSA of mesopore and macropore compared to samples in well $\mathrm{BC} 1$. Meanwhile, the relationship of incremental PV and PW of shale samples in well TC1 and well BC1 have similar characteristics compared to SSA (Fig. 7).

\section{SSA and PV for pore space in different scales}

Based on the IUPAC, the pore in different scales can be divided into macropore, mesopore and micropore, corresponding diameters of which are $>50,2-50$ and $<2 \mathrm{~nm}$, respectively. Based on this, the SSA of different pore 

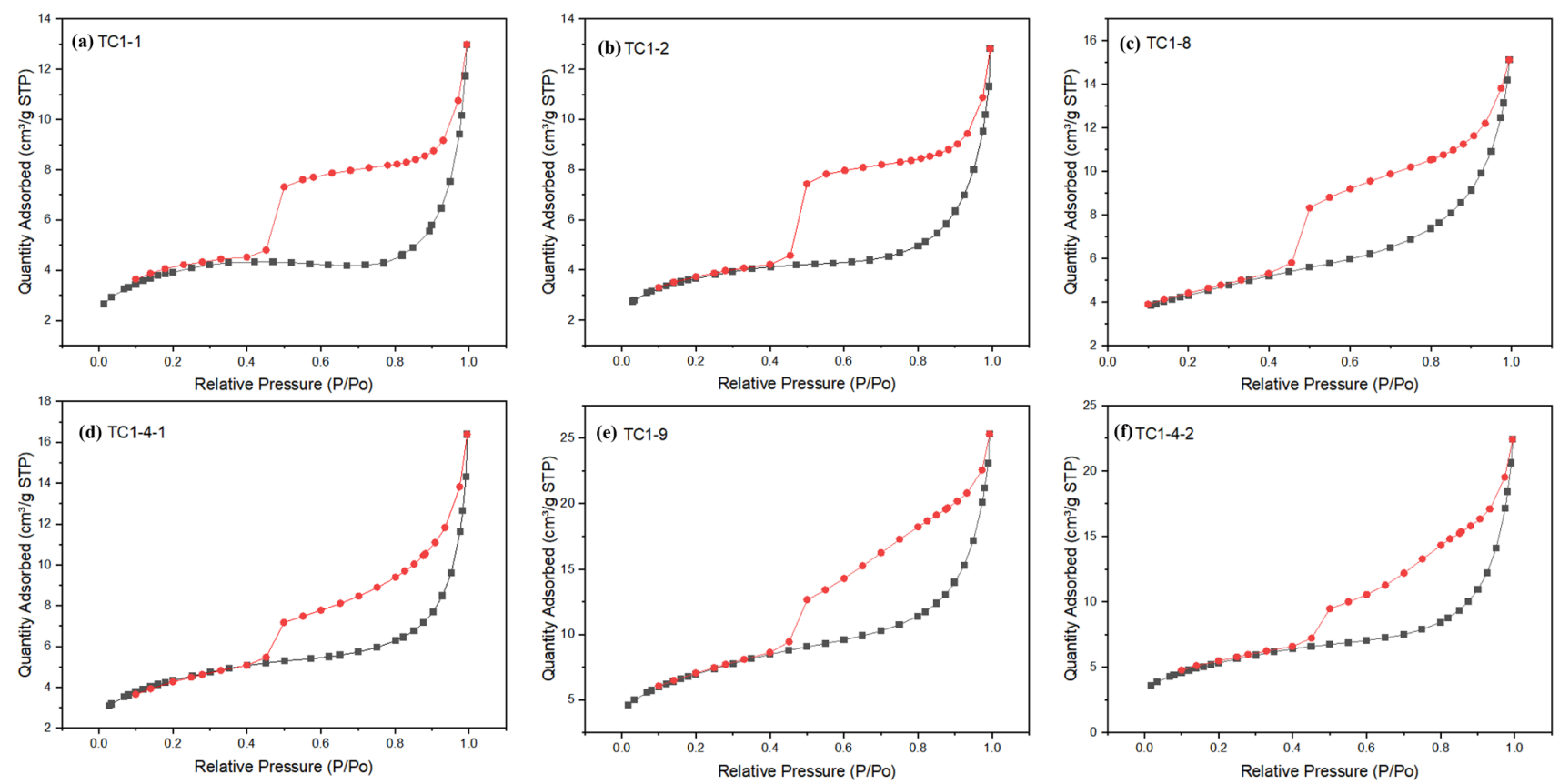

Fig. 4 Adsorption-desorption isotherms of $\mathrm{N}_{2}$ for the shale samples from Well TC1 in the Southern North China basin
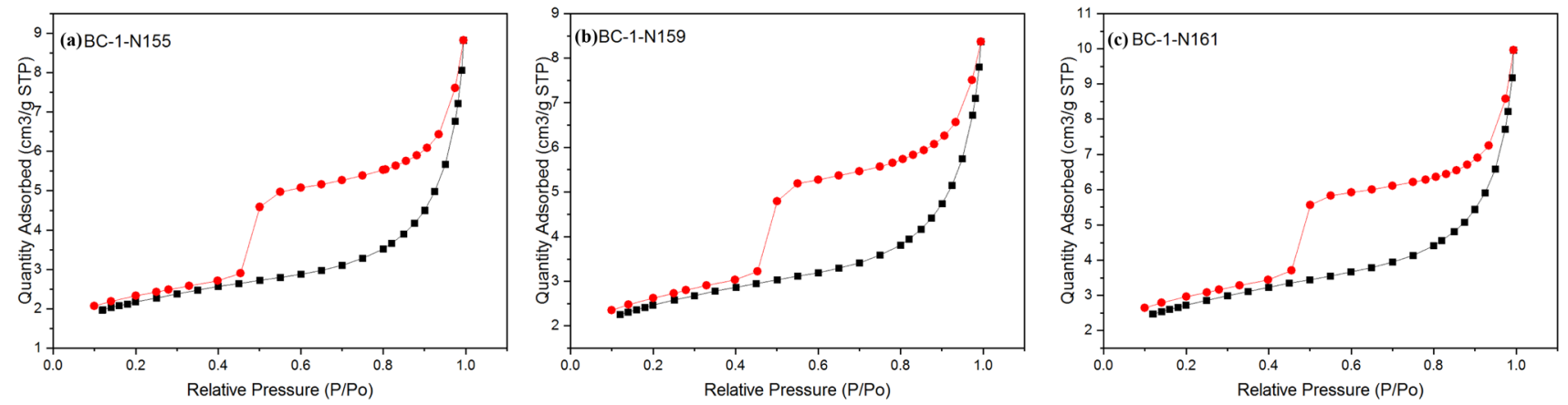

Fig. 5 Adsorption-desorption isotherms of $\mathrm{N}_{2}$ for the shale samples from Well BC1 in the Southern North China basin

Fig. 6 Incremental pore area vs. pore width of shale samples (a Well TC1; b Well BC1)
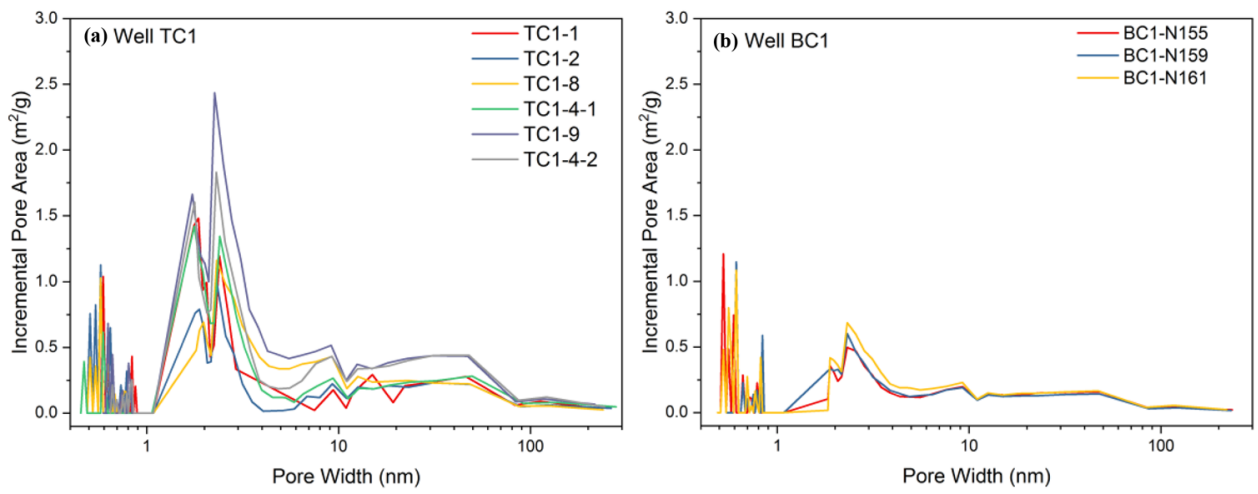
Fig. 7 Incremental pore volume vs. pore width of shale samples (a Well TC1; b Well BC1)
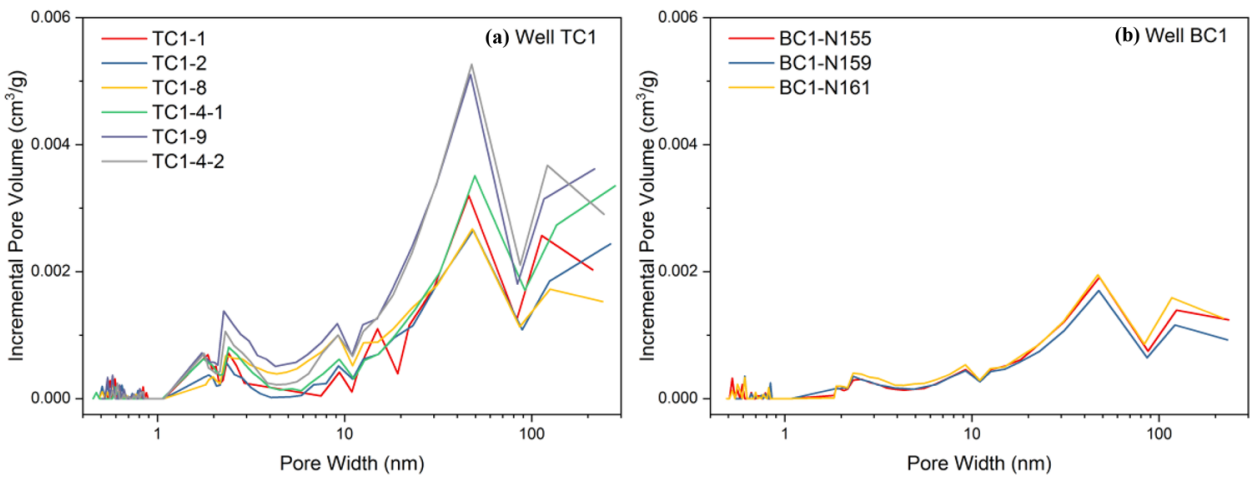

scale and PV of the shale from well TC1 and well BC1 in different scales were presented in Table 2. The total SSA of shale from well TC1 ranges from 11.3000 to $24.9882 \mathrm{~m}^{2} / \mathrm{g}$, averaging at $15.9728 \mathrm{~m}^{2} / \mathrm{g}$. Whereas, the total SSA of shale from well BC1 ranges from 7.6711 to $10.2719 \mathrm{~m}^{2} / \mathrm{g}$, averaging at $8.7895 \mathrm{~m}^{2} / \mathrm{g}$. The results show that the shale from well TC1, which have been suffered multistage tectonic uplifts, are characterized by greater SSA compared with shale samples from well BC1 with a continuing deposition. In addition, among the different scales of pores, the SSA of micropore in shale from Well TC1 is average at $6.2503 \mathrm{~m}^{2} / \mathrm{g}$, which is obviously greater than that of samples from Well BC1 $\left(3.9030 \mathrm{~m}^{2} / \mathrm{g}\right.$ in average). Moreover, the SSA of mesopore in shale from Well TC1 is averaging at $9.5232 \mathrm{~m}^{2} / \mathrm{g}$, which is obviously greater than that of samples from Well BC1 $\left(4.6298 \mathrm{~m}^{2} / \mathrm{g}\right.$ in average). However, the samples from two wells are characterized by almost similar SSA of macropore. Meanwhile, the characteristics of PV in macropore, mesopore and micropore are similar with the SSA. Also, the proportion of macropore, mesopore and micropore in PV and SSA of two different wells are almost the same (Fig. 8).

\section{Heterogeneity of pore system}

Generally, fractal dimension $\left(D_{f}\right)$ is a quantitative parameter to demonstrate the heterogeneous pore structure of clastic rocks, including tight sandstone and shale (Guo et al. 2020; Pfeifer and Avnir 1983). Varying models were proposed to calculate $\mathrm{D}_{\mathrm{f}}$ (Avnir and Jaroniec 1989; Bernal and Bello 2001; Jaroniec 1995; Rouquerol et al. 1994). Among those models, fractal Frenkel-Halsey-Hill (FHH) is an effective model to achieve the $\mathrm{D}_{\mathrm{f}}$ (Shang et al. 2020; Xu et al. 2020). The FHH $D_{f}$ can be directly acquired by low pressure $\mathrm{N}_{2}$ adsorption experimental results using following equation:

$\ln \mathrm{V}=\lambda \times \ln \left(\ln \frac{\mathrm{P} 0}{\mathrm{P}}\right)+\mathrm{K}$

where $\mathrm{V}$ represents the adsorbed volume of $\mathrm{N}_{2}$ at the balance pressure $\mathrm{p}, \mathrm{cm}^{3} / \mathrm{g}, \mathrm{P}_{0}$ is the saturated pressure of $\mathrm{N}_{2}$, $\mathrm{MPa}, \lambda$ is the linear correction coefficient, and $\mathrm{K}$ is the constant. Based on this, the FHH model $\mathrm{D}_{\mathrm{f}}$ can be acquired by follow equation (Xu et al. 2015):

\section{$\mathrm{D}=\lambda+3$.}

The FHH $\mathrm{D}_{\mathrm{f}}$ of shale from well TC1 and well BC1 were presented in Table 3. The pressure has been divided into two parts for linear fitting, including $\mathrm{P} / \mathrm{P}_{0}=0-0.45$ and $\mathrm{P} /$ $\mathrm{P}_{0}=0.45-1$. Generally, $\mathrm{D}_{1}$, which can be calculated during

Table 2 The pore volume and specific surface area of the shale of well TC1 and well BC1 in different scales

\begin{tabular}{|c|c|c|c|c|c|c|c|c|c|}
\hline \multirow[t]{2}{*}{ Area } & \multirow[t]{2}{*}{ Samples } & \multicolumn{4}{|c|}{ Specific surface area $\left(\mathrm{m}^{2} / \mathrm{g}\right)$} & \multicolumn{4}{|c|}{ Pore volume $\left(\mathrm{cm}^{3} / \mathrm{g}\right)$} \\
\hline & & Total & Micropore & Mesopore & Macropore & Total & Micropore & Mesopore & Macropore \\
\hline \multirow[t]{6}{*}{ Well TC1 } & TC1-1 & 13.7170 & 6.8687 & 6.6597 & 0.1885 & 0.0200 & 0.0026 & 0.0116 & 0.0058 \\
\hline & TC1-2 & 11.3000 & 6.1676 & 4.9874 & 0.1451 & 0.0187 & 0.0022 & 0.0112 & 0.0054 \\
\hline & TC1-8 & 14.5690 & 4.9349 & 9.5011 & 0.1329 & 0.0229 & 0.0018 & 0.0167 & 0.0044 \\
\hline & TC1-4-1 & 13.8090 & 4.8922 & 8.7141 & 0.2026 & 0.0251 & 0.0021 & 0.0152 & 0.0078 \\
\hline & TC1-9 & 24.9882 & 8.8100 & 15.9173 & 0.2609 & 0.0388 & 0.0034 & 0.0269 & 0.0086 \\
\hline & TC1-4-2 & 17.4537 & 5.8285 & 11.3594 & 0.2658 & 0.0342 & 0.0024 & 0.0231 & 0.0087 \\
\hline \multirow[t]{3}{*}{ Well BC1 } & BC1-N155 & 8.4256 & 4.0150 & 4.1509 & 0.2596 & 0.0137 & 0.0013 & 0.0070 & 0.0053 \\
\hline & BC1-N159 & 7.6711 & 3.0736 & 4.3711 & 0.2264 & 0.0124 & 0.0012 & 0.0068 & 0.0044 \\
\hline & BC1-N161 & 10.2719 & 4.6206 & 5.3675 & 0.2837 & 0.0154 & 0.0016 & 0.0081 & 0.0057 \\
\hline
\end{tabular}




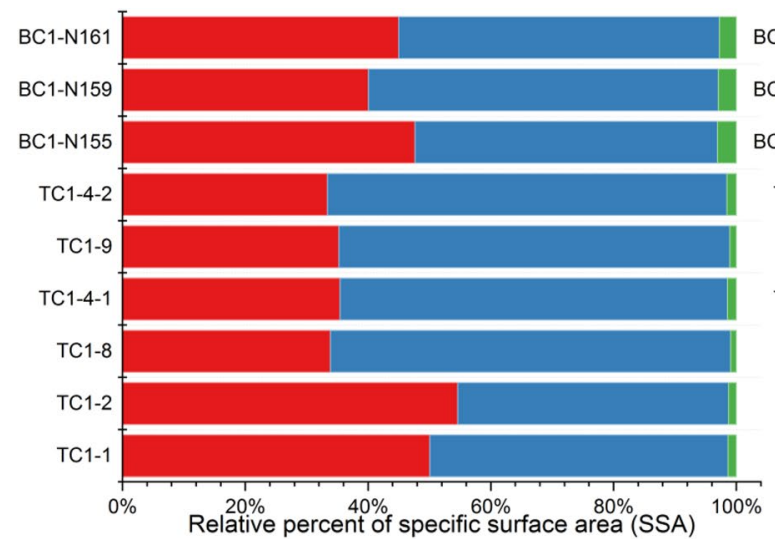

(a)

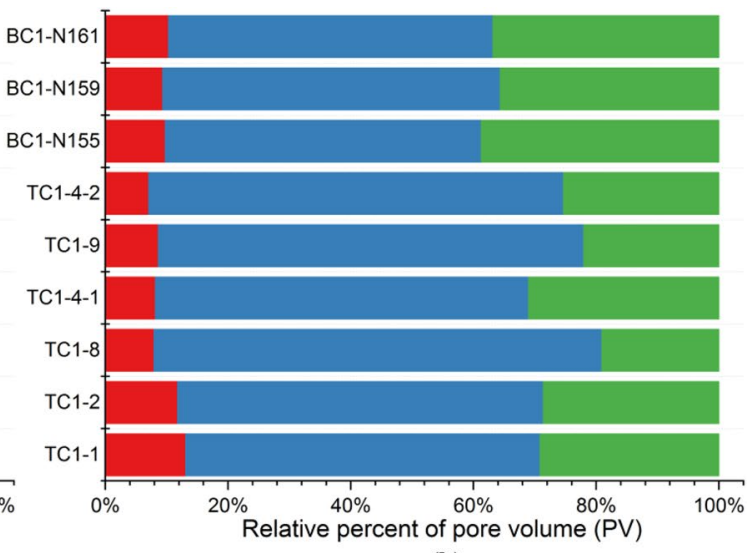

(b)

macropore

mesopore

micropore

Fig. 8 Relative percent of a specific surface area and $\mathbf{b}$ pore volume of macropore, mesopore and micropore of shale in well TC1 and well BC1

Table 3 FHH fractal dimension of shale from Well TC1 and Well BC1

\begin{tabular}{|c|c|c|c|c|c|c|c|}
\hline \multirow[t]{2}{*}{ Area } & \multirow[t]{2}{*}{ Samples } & \multicolumn{3}{|c|}{$\mathrm{P} / \mathrm{P}_{0}(0-0.45)$} & \multicolumn{3}{|c|}{$\mathrm{P} / \mathrm{P}_{0}(0.45-1)$} \\
\hline & & $\lambda_{1}$ & $\mathrm{R}^{2}$ & $\mathrm{D}_{1}=3+\lambda_{1}$ & $\lambda_{2}$ & $\mathrm{R}^{2}$ & $\mathrm{D}_{2}=3+\lambda_{2}$ \\
\hline \multirow[t]{6}{*}{ Well TC1 } & TC1-1 & -0.3203 & 0.9512 & 2.6797 & -0.2652 & 0.9478 & 2.7348 \\
\hline & TC1-2 & -0.3053 & 0.9763 & 2.6947 & -0.2475 & 0.9846 & 2.7525 \\
\hline & TC1-8 & -0.3351 & 0.9983 & 2.6649 & -0.2207 & 0.9811 & 2.7793 \\
\hline & TC1-4-1 & -0.3512 & 0.9806 & 2.6488 & -0.2443 & 0.9918 & 2.7557 \\
\hline & TC1-9 & -0.4028 & 0.9935 & 2.5972 & -0.2358 & 0.9937 & 2.7642 \\
\hline & TC1-4-2 & -0.3811 & 0.9914 & 2.6189 & -0.2767 & 0.9881 & 2.7233 \\
\hline \multirow[t]{3}{*}{ Well BC1 } & BC1-N155 & -0.3060 & 0.9963 & 2.6940 & -0.2628 & 0.9896 & 2.7372 \\
\hline & BC1-N159 & -0.2793 & 0.9954 & 2.7207 & -0.2286 & 0.9905 & 2.7714 \\
\hline & BC1-N161 & -0.3145 & 0.9976 & 2.6855 & -0.2390 & 0.9950 & 2.7610 \\
\hline
\end{tabular}

$\mathrm{P} / \mathrm{P}_{0}=0-0.45$, can reflect the heterogeneous of surface roughness and pore structure for micropore at low pressure. Whereas, $\mathrm{D}_{2}$ from $\mathrm{P} / \mathrm{P}_{0}=0.45-1$ usually acts as an indicator for the irregularity of pore network and relative great pores at higher pressure (Shang et al. 2020). It is well accepted the $\mathrm{D}_{\mathrm{f}}$ increases as the irregular geometric of shale pore structure becomes more complex. Based on the calculation, the $\mathrm{D}_{1}$ and $\mathrm{D}_{2}$ for well TC1 have averages of 2.6507 and 2.7516, respectively. Meanwhile, the $\mathrm{D}_{1}$ and $\mathrm{D}_{2}$ for Well $\mathrm{BC} 1$ have averages of 2.700 and 2.7565 , respectively. The results indicate that the shale with a multistage tectonic uplift has a less $\mathrm{D}_{\mathrm{f}}$ of $\mathrm{D}_{1}$ in $\mathrm{P} / \mathrm{P}_{0}=0-0.45$ and similar $\mathrm{D}_{2}$ in $\mathrm{P} / \mathrm{P}_{0}=0.45-1$ compared to shale with a continuing deposition.

\section{Methane adsorption capacity}

Measured and fitted excess adsorption amount $\left(\mathrm{V}_{\mathrm{ex}}\right)$ for samples from wells TC1 and BC1 were presented in Fig. 9. Based on this, fitted Langmuir pressure and volume of the Taiyuan shale samples in wells BC1 and TC1 can be calculated, and the fitting results were presented in Table 4 . The

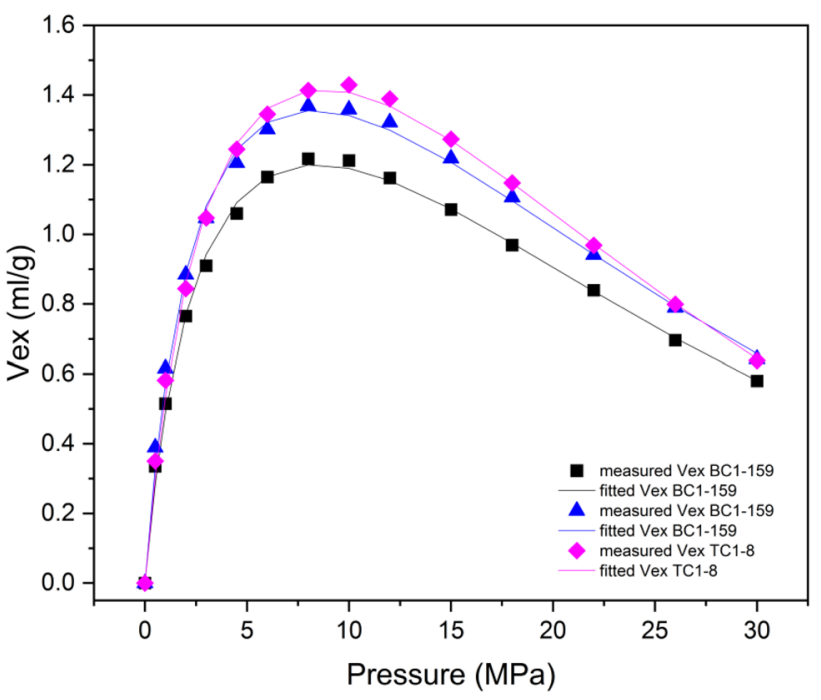

Fig. 9 Measured and fitted excess adsorption amount $\left(\mathrm{V}_{\mathrm{ex}}\right)$ for samples from wells TC1 and $\mathrm{BC} 1$ 
Table 4 Fitted Langmuir pressure and Langmuir volume of the Taiyuan shale of Well BC1 and TC1

\begin{tabular}{lllll}
\hline Samples & Depth $(\mathrm{m})$ & Formation & $\begin{array}{l}\mathrm{V}_{\mathrm{L}} \\
\mathrm{cm}^{3} / \mathrm{g}\end{array}$ & $\begin{array}{l}\mathrm{P}_{\mathrm{L}} \\
\mathrm{MPa}\end{array}$ \\
\hline BC1-N155 & 2713.79 & Taiyuan & 2.05 & 3.08 \\
BC1-N159 & 2716.74 & Taiyuan & 2.27 & 2.86 \\
TC1-8 & 1508.50 & Taiyuan & 2.58 & 3.70 \\
\hline
\end{tabular}

results show that the $\mathrm{V}_{\mathrm{L}}$ of Taiyuan shale from well $\mathrm{BC} 1$ ranges from 2.05 to $2.27 \mathrm{~cm}^{3} / \mathrm{g}$. However, the $\mathrm{V}_{\mathrm{L}}$ of Taiyuan shale from well TC1 is $2.58 \mathrm{~cm}^{3} / \mathrm{g}$, which is greater than shales from well $\mathrm{BC} 1$. Meanwhile, the $\mathrm{P}_{\mathrm{L}}$ for Taiyuan shale from well $\mathrm{TC} 1$ is greater than that of well $\mathrm{BC} 1$.

In general, the results reveal that the adsorbing capacity of shale from well TC1 is greater than that of well TC1, which may be influenced by PV and SSA of micropores and mesopores of shale samples. It is concluded in this study that the PV and SSA of micropores and mesopores of shale samples with multi-stage tectonic uplift have increased significantly, which may obviously affect the methane adsorption capacity of shale sample.

\section{Influence mechanism of depositional and burial processes on shale pore structure}

The experimental results indicate that the pore structure of the continuously deposited shale samples (well BC1) are obviously different from that of the shale sample (well TC1) which has experienced multi-stage uplift. Samples from well TC1 have larger SSA, PV, methane adsorption capacity and rougher pore surface of micro- as well as meso-pores. In general, the Taiyuan shale in those two wells are of almost same TOC contents and organic matters type. The TOC contents of Taiyuan shale from well TC1 range from 1.06 to $2.02 \%$, with an average of $1.56 \%$. The TOC contents in Well $\mathrm{BC} 1$ range from 1.23 to $1.89 \%$, with an average of $1.46 \%$. In addition, the Taiyuan Formation shale of the two area are all type III organic matters. However, apart from organic matters types and contents, the vitrinite reflectance (Ro), clay mineral contents and depositional and burial processes of the Taiyuan shale from two wells are different.

\section{Vitrinite reflectance (Ro)}

The vitrinite reflectance $\left(\mathrm{R}_{\mathrm{o}}\right)$ of the Taiyuan shale in Well $\mathrm{BC} 1$ is $\sim 3.0 \%$, and that of Well TC1 is $\sim 1.0 \%$. The difference in Ro is related to the different depositional and burial processes of the shale from two different wells. According to the previous research findings of thermal simulation on the evolution features of shale pore structure, the PV and SSA increase to a certain extent with the increase of maturity (Chen et al. 2019; Zhang et al. 2020c). At the same time, Mark et al (2012) carried out the research on the evolvement feature of shale pore structure under natural section conditions, and the results showed that the early stage liquid hydrocarbon cracked, and the shale pores were released along with the improvement of maturity. This is in line with the comparative study on pore structure of shale before and after extraction of soluble organic matter by Wang et al (2020). Xu et al (2019a) carried out thermal simulation experiments on the pore structure evolution of typical type II kerogen source rocks, and the results revealed different evolution stages of pore adjustment, development, transformation and destruction (Fig. 10). Meanwhile, it also showed that the SSA and PV gradually increased in the wet gas formation period of oil cracking. Shale in Well BC1 has entered the over mature stage, and the pore space especially the organic pore will be further released with the cracking of liquid hydrocarbon, while shale in Well TC1 is still in the oil generation window stage, in which the liquid hydrocarbon will occupy a certain pore space. Therefore, shale in Well TC1 should have smaller SSA and PV if other factors are not considered, which is inconsistent with the actual experimental results, indicating that maturity is not the dominant factor determining the different physical parameters of shale in different sedimentary burial processes.

\section{Clay mineral contents}

The organic pores in the studied samples are relatively undeveloped. From the FE-SEM images, the pore structure is mainly contributed by inorganic pores (Fig. 3a-f), which is consistent with the previous study, the marine-continental transitional shale pore structure is more closely related to clay minerals (Li et al. 2019; Yang et al. 2017).

The influence factors of organic pore and inorganic pore are also different. For inorganic pore, it is mainly affected by mineral type, compaction, burial cementation, while for organic pore, it is chiefly thermal evolution, organic matter types and abundance (Liu et al. 2020b). The clay mineral content in shale from different Wells is also different. For TC1 shale samples, the total clay mineral content of TC1 and $\mathrm{BC} 1$ shale samples ranges from $15-42 \%$ and $19-20 \%$, averaging at 30.5 and $19.3 \%$, respectively. TC1 shale generally contains higher clay mineral content than $\mathrm{BC} 1$ shale, leading to larger SSA and PV of TC1 shale. Whereas, for samples with similar clay mineral content, SSA and PV of $\mathrm{TC} 1$ shale are much larger than those of $\mathrm{BC} 1$ (e.g., TC11, TC1-9, BC1-N155 and BC1-N161). Hence, though clay mineral content is closely related to pore structure basically, it is not the main controlling factor for Taiyuan shale in this study. 


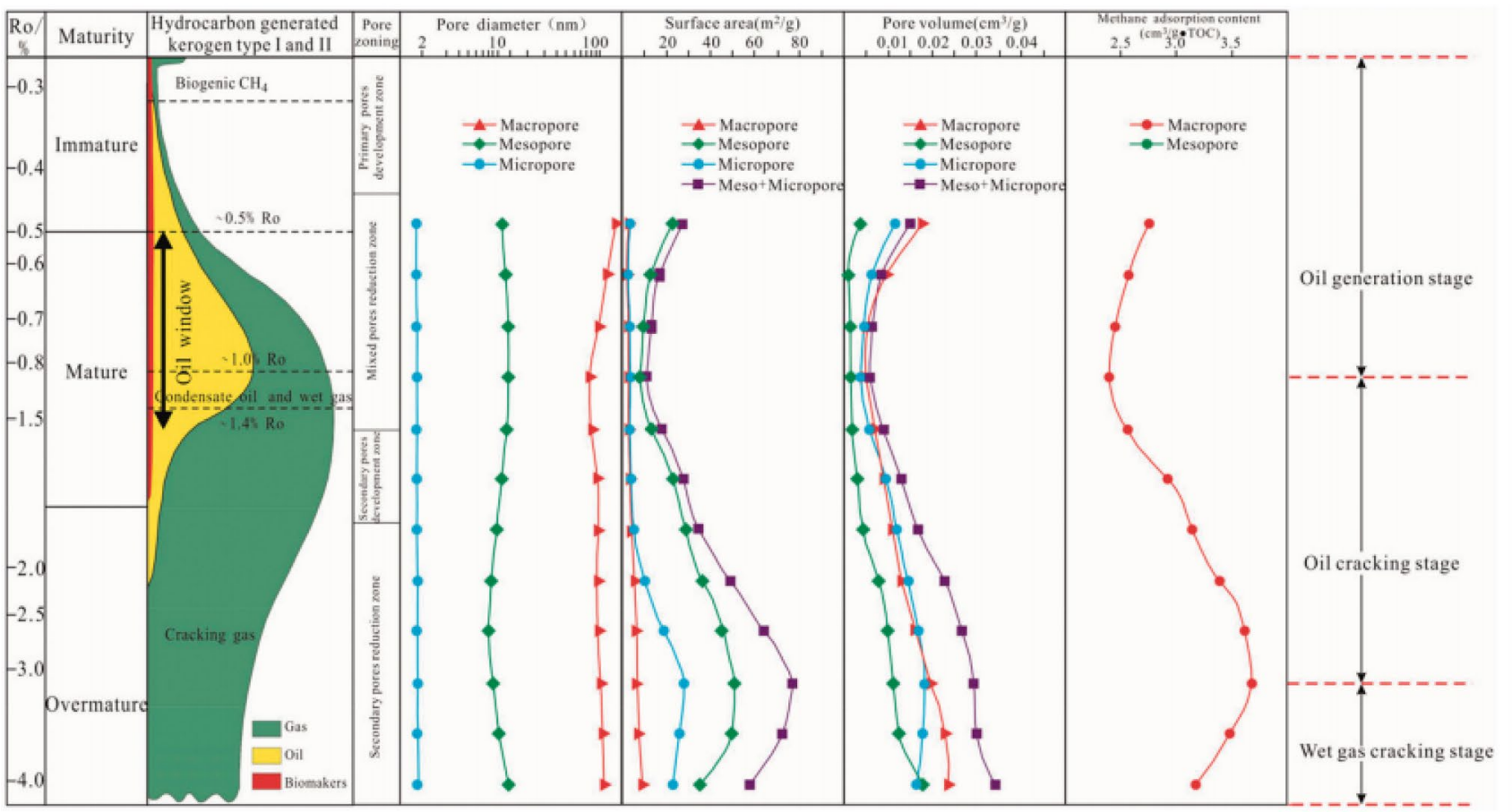

Fig. 10 Pore evolution of shale (Xu et al. 2019a)

\section{Depositional and burial processes}

Influenced by Indosinian, Yanshanian and Himalayan movements, the Carboniferous-Permian strata in Zhoukou depression experienced multiple subsidence and uplift, and the depositional and burial processes of different tectonic units are quite different (Meng et al. 2019). During the Indosinian movement, the Fuyang-Bozhou area was dominated by compressional fold, thrust uplift and denudation, and the intensity of tectonic activity gradually weakened from South to North. Specifically, there is no residue of Triassic strata in Niqiuji sag and Gucheng uplift, and the denudation thickness is more than $2000 \mathrm{~m}$, while the tectonic strength in Yanji sag is relatively weak, so the Yanji sag is dominated by normal sedimentary burial, and the strata are well preserved. Due to the enhanced intra-continental collision inside the Dabie Mountains in late Yanshanian (late Cretaceous), the study area was dominated by compression and uplift, resulting in the loss of Crestaceous strata in each tectonic belt, while the denudation thickness of Yanji sag and Wanglou slope in the North was less, which is about $100 \mathrm{~m}$ (Li et al. 2021). There was a short basin forming period in Paleogene because of the shear and extension in the study area. After Neogene, regional depression occurred and the sedimentary process began in the study area (Liang et al. 2017). On the basis of the above analysis, the burial history of typical drilling in Wanglou slope (BC1) and Gucheng uplift (TC1) is restored by using the stratum stripping method, in which the stratum thickness, top and bottom depth and other parameters are determined according to the actual drilling and completion report. Figure 11 shows the sedimentary burial history of the two different areas. For the continuous sedimentation shale sample (well BC1) and multi-stage uplift sample (well TC1) involved in this study, well TC1 experienced early deep burial, late strong uplift, strong denudation and deformation, that is, deep burial and strong transformation process. The Carboniferous-Permian organic rich shale strata were at the maximum burial depth in the Triassic. Due to the late tectonic uplift, diagenesis and hydrocarbon generation stopped. Hence, the shale samples of well TC1 have larger micropores with the SSA and PV. While the coarser pore surface of mesopores may not be related to thermal maturation, but be caused by depositional and burial processes. Previous experiments on overburden porosity show that the pores and micro-fractures of shale will gradually close in the process of pressurization, while most of the closed pores and micro-fractures will reopen during pressure relief, and only part of plastic deformation will cause irreversible pore damage (He et al. 2017; Wang et al. 2018). Due to the decrease of overburden pressure and the change of in-situ stress, the mechanical properties of shale are changed, unloading micro fractures are formed between grains and laminae, and the physical properties of reservoir are improved (He et al. 2017). The tectonic

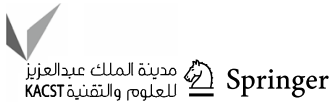



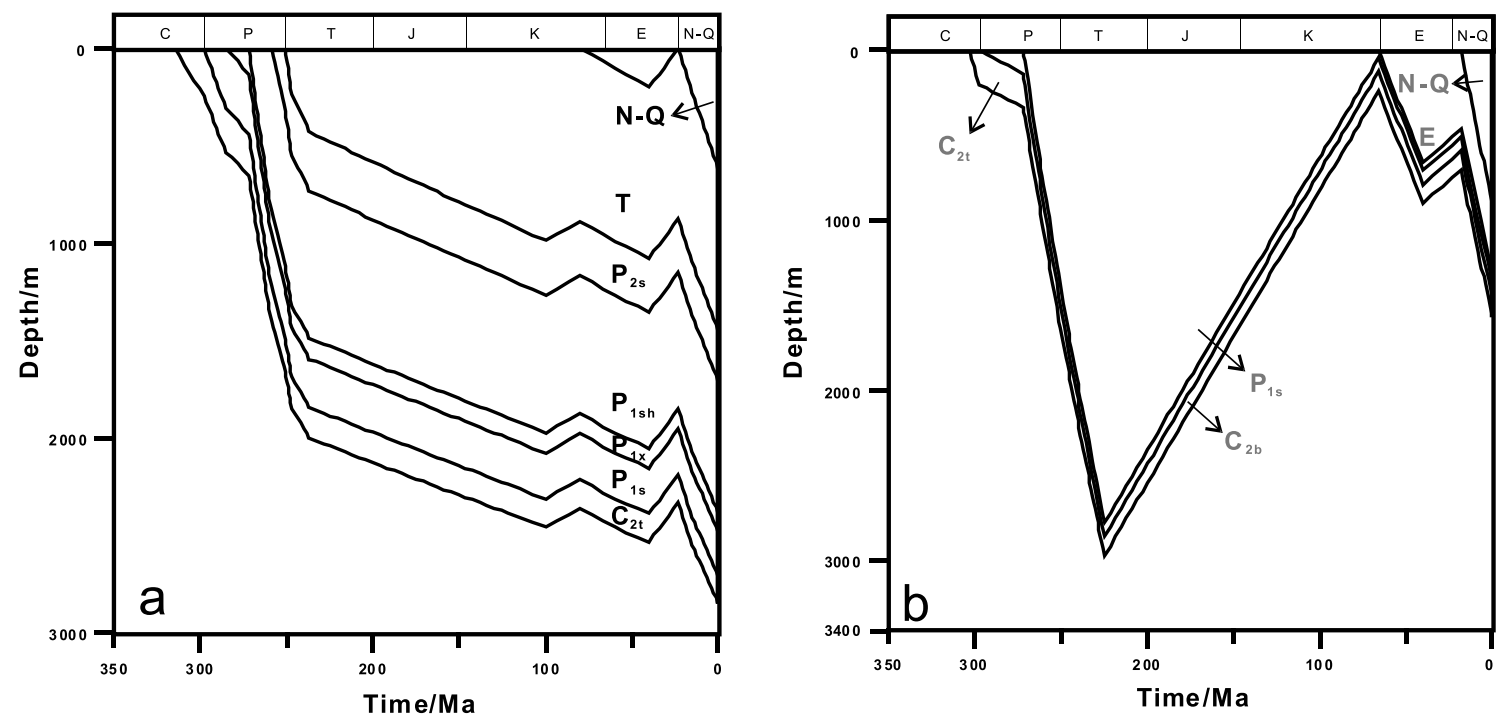

Fig. 11 Burial history of $\mathrm{BC} 1$ (a) and $\mathrm{TC} 1(\mathbf{b})$

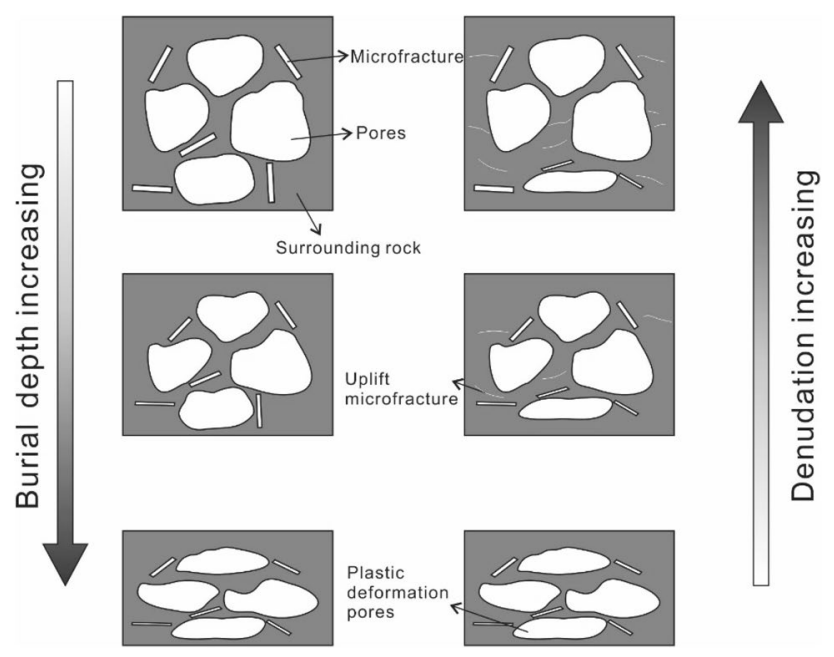

Fig. 12 Conceptual diagram of pore structure evolution related to tectonic burial and uplift

uplift reduces the bottom load pressure, while the pores of deeper shale will be flattened when the loading pressure is higher. Meanwhile, in the process of tectonic uplift, the overlying strata stress of shale will gradually decrease with the decrease of burial depth, which makes the compressed pores recover to a certain extent, improving the pore space condition, and increases the occurrence space of shale gas (Fig. 12). Nevertheless, the real influence process of different depositional and burial processes on pore structure and methane adsorption capacity of transition shale cannot be completely reproduced in this study. This study focused on the final impact result rather than the evolution process.

\section{Implication for Shale gas exploration and future studies}

In terms of shale gas exploration, intuitively speaking, shale under multi-stage tectonic uplift with larger SSA and PV of micro- and mesopores and greater methane adsorption capacity obviously has better shale gas accumulation and exploration potential. However, the real situation may be more complex. Relevant studies generally believe that tectonic uplift itself can improve shale physical properties and methane adsorption capacity and is conducive to the formation of overpressure shale gas enrichment (Liu et al. 2015; Shang et al. 2020; Xu et al. 2019b). Nevertheless, faults and large fractures caused by tectonic deformation associated with tectonic uplift will lead to the escape of shale gas (He et al. 2020). During actual drilling process, there are four abnormal gas logging layers in Taiyuan Formation of well $\mathrm{BC} 1$, which are $12 \mathrm{~m}$ in length. The highest gas logging total hydrocarbon is $0.82 \%$ (drilling fluid density is $1.3 \mathrm{~g} / \mathrm{cm}^{3}$ ), which is more than ten times of the background value. However, in Taiyuan shale from well TC1, the gas logging anomaly is 1 layer with $1 \mathrm{~m}$, and the maximum gas logging total hydrocarbon is $0.18 \%$ (drilling fluids density is $1.14 \mathrm{~g} / \mathrm{cm}^{3}$ ), which is only 3 times of the background value. This may be related to the fracture communication caused by tectonic uplift, leading to the extensive shale gas wastage. Besides, when the shale is uplifted to a lower depth, the microbial activity will also increase. Some related studies have shown that a large amount of coalbed methane, which belongs to secondary biogas, is produced by microbial action when the source rocks are uplifted to a shallow depth (Wang et al. 2018). Tectonic evolution is an important dynamic subsystem of shale gas enrichment system as the different strength 
has a distinct effect on the preservation of shale gas ( $\mathrm{Li}$ and Ou 2018). In view of the complexity of the tectonic activities impact on shale gas enrichment and preservation, the prospective exploration potential of Well $\mathrm{BC} 1$ and $\mathrm{TC} 1$ still needs further detailed and comprehensive analysis.

\section{Conclusions}

The shale core samples of Taiyuan Formation, which were deposited continuously and experienced multi-stage tectonic uplift in Fuyang-Bozhou area of SNCB were collected, respectively. On this basis, the TOC contents, mineral components, low-pressure $\mathrm{N}_{2}$ and $\mathrm{CO}_{2}$ adsorption, high-pressure methane adsorption and argon ion polishing FE-SEM observing were conducted to study the influence of tectonic uplift on shale reservoir physical properties and adsorption performance. The main conclusions are listed as following:

1. The pore structure features of the Taiyuan shale in Fuyang-Bozhou area of SNCB with multi-stage tectonic uplift and continues deposition were compared. The results show that the pore types and characteristics have no obvious variation, while the PV and SSA of micropores and mesopores of shale samples under multi-stage tectonic uplift have increased significantly. Meanwhile, the roughness of shale pores increases also.

2. For the shale in Fuyang-Bozhou area of SNCB. The decrease of loading pressure caused by multi-stage tectonic uplift may be the main factors for the pore structure changes of shale.

3. Compared with the continuous deposited samples, the shale samples under multi-stage tectonic uplift have stronger methane adsorption capacity, which is relevant to the greater SSA of micropores and mesopores.

Acknowledgements This work was financial supported by the National Natural Science Foundation of China (Grant No.42002173 and 41702017), and China Geological Survey project (DD20190725); Science Foundation of China University of Petroleum (Beijing) under Grant 2462015YJRC015; and the State Key lab Petr. Resources \& Prospecting under Grant PRP/indep-4-1521 and PRP/indep-3-1811

Funding The National Natural Science Foundation of China (Grant No.42002173 and 41702017), and China Geological Survey project (DD20190725); Science Foundation of China University of Petroleum (Beijing) under Grant 2462015YJRC015; and the State Key lab Petr. Resources \& Prospecting under Grant PRP/indep-4-1521 and PRP/ indep-3-1811.

Open Access This article is licensed under a Creative Commons Attribution 4.0 International License, which permits use, sharing, adaptation, distribution and reproduction in any medium or format, as long as you give appropriate credit to the original author(s) and the source, provide a link to the Creative Commons licence, and indicate if changes were made. The images or other third party material in this article are included in the article's Creative Commons licence, unless indicated otherwise in a credit line to the material. If material is not included in the article's Creative Commons licence and your intended use is not permitted by statutory regulation or exceeds the permitted use, you will need to obtain permission directly from the copyright holder. To view a copy of this licence, visit http://creativecommons.org/licenses/by/4.0/.

\section{References}

Avnir D, Jaroniec M (1989) An isotherm equation for adsorption on fractal surfaces of heterogeneous porous materials. Langmuir 5:1431-1433

Bernal J, Bello MA (2001) Fractal geometry and mercury porosimetry: comparison and application of proposed models on building stones. Appl Surf Sci 185:99-107

Brunauer S, Deming LS, Deming WE, Teller E (1940) On a Theory of the van der Waals Adsorption of Gases. J Am Chem Soc 62:1723-1732

Cai YD, Liu DM, Pan ZJ, Yao YB, Li JQ, Qiu YK (2013) Pore structure and its impact on $\mathrm{CH} 4$ adsorption capacity and flow capability of bituminous and subbituminous coals from Northeast China. Fuel 103:258-268

Chen G, Lu S, Liu K, Xue Q, Qi Q (2019) Investigation of pore size effects on adsorption behavior of shale gas. Mar Pet Geol 109:1-8

Guo H, Jia W, Peng PA, Lei Y, Luo X, Cheng M, Wang X, Zhang L, Jiang C (2014) The composition and its impact on the methane sorption of lacustrine shales from the Upper Triassic Yanchang Formation, Ordos Basin, China. Mar Petrol Geol 57:509-520

Guo R, Xie Q, Qu X, Chu M, Li S, Ma D, Ma X (2020) Fractal characteristics of pore-throat structure and permeability estimation of tight sandstone reservoirs: a case study of Chang 7 of the Upper Triassic Yanchang Formation in Longdong area, Ordos Basin, China. J Petrol Sci Eng 184:106555

He Z, Hu Z, Nie H, Li S, Xu J (2017) Characterization of shale gas enrichment in the Wufeng-Longmaxi Formation in the Sichuan Basin and its evaluation of geological construction-transformation evolution sequence. Nat Gas Geosci 28:724-733

He ZL, Nie HK, Li SJ, Luo J, Wang H, Zhang GR (2020) Differential enrichment of shale gas in upper Ordovician and lower Silurian controlled by the plate tectonics of the Middle-Upper Yangtze, south China. Mar Petrol Geol 118:12

Hu H, Hao F, Guo X, Dai F, Lu Y, Ma Y (2018) Investigation of methane sorption of overmature Wufeng-Longmaxi shale in the Jiaoshiba area, Eastern Sichuan Basin, China. Mar Petrol Geol 91:251-261

Jaroniec M (1995) Evaluation of the fractal dimension from a single adsorption isotherm. Langmuir 11:2316-2317

Li C, Ou C (2018) Modes of shale-gas enrichment controlled by tectonic evolution. Acta Geol Sin Engl Ed 92:1934-1947

Li P, Zhang JC, Tang X, Huo ZP, Li Z, Luo KY, Li ZM (2021) Assessment of shale gas potential of the lower Permian transitional Shanxi-Taiyuan shales in the southern North China Basin. Aust J Earth Sci 68:262-284

Li Q, Pang X, Tang L, Chen G, Shao X, Jia N (2018) Occurrence features and gas content analysis of marine and continental shales: a comparative study of Longmaxi Formation and Yanchang Formation. J Nat Gas Sci Eng 56:504-522

Li Y, Wang Z, Pan Z, Niu X, Yu Y, Meng S (2019) Pore structure and its fractal dimensions of transitional shale: a cross-section from east margin of the Ordos Basin, China. Fuel 241:417-431

Liang C, Jiang ZX, Cao YC, Zhang JC, Guo L (2017) Sedimentary characteristics and paleoenvironment of shale in the

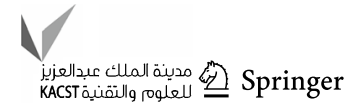


Wufeng-Longmaxi Formation, North Guizhou Province, and its shale gas potential. J Earth Sci 28:1020-1031

Liu H, Guo W, Fang C, Wang H (2015) A study on geological characteristics of marine shale gas reservoir in Southern China. Energy Explor Exploit 33:299-308

Liu P, Wang XF, Li XF, Zhang T, Du GC, Liu WH (2020a) Competitive adsorption characteristics of $\mathrm{CH} 4 / \mathrm{C} 2 \mathrm{H} 6$ gas mixtures on model substances, coal and shale. Fuel 279:9

Liu S, Ye Y, Ran B, Jiang L, Li Z, Li J, Song J, Jiao K, Li Z, Li Y (2020b) Evolution and implications of shale pore structure characteristics under different preservation conditions. Reser Eval Develop 10:1-11

Liu XG, Li SZ, Zhang J, Li XY, Zhao SJ, Dai LM, Wang GZ (2019) Meso-Neoproterozoic strata and target source rocks in the North China Craton: A review. Precambr Res 334:22

Loucks RG, Reed RM, Ruppel SC, Hammes U (2012) Spectrum of pore types and networks in mudrocks and a descriptive classification for matrix-related mudrock pores. AAPG Bull 96:1071-1098

Mark EC, Brian JC, Carl H (2012) Development of organic porosity in the Woodford Shale with increasing thermal maturity. Int $\mathbf{J}$ Coal Geol

Martini AM, Walter LM, Budai JM, Ku T, Kaiser CJ, Schoell M (1998) Genetic and temporal relations between formation waters and biogenic methane: Upper Devonian Antrim Shale, Michigan Basin, USA. Geochim Cosmochim Acta 62:1699-1720

Meng QR, Wu GL, Fan LG, Wei HH (2019) Tectonic evolution of early Mesozoic sedimentary basins in the North China block. Earth Sci Rev 190:416-438

Pfeifer P, Avnir D (1983) Chemistry in noninteger dimensions between two and three. I. Fractal theory of heterogeneous surfaces. J Chem Phys 79:3558-3565

Radwan AE (2021) Modeling pore pressure and fracture pressure using integrated well logging, drilling based interpretations and reservoir data in the giant El Morgan oil field, Gulf of Suez, Egypt. J Afr Earth Sci 178

Radwan AE, Abudeif AM, Attia MM, Elkhawaga MA, Abdelghany WK, Kasem AA (2020) Geopressure evaluation using integrated basin modelling, well-logging and reservoir data analysis in the northern part of the Badri oil field, Gulf of Suez, Egypt. J Afr Earth Sci 162

Radwan AE, Abudeif AM, Attia MM, Mohammed MA (2019) Pore and fracture pressure modeling using direct and indirect methods in Badri Field, Gulf of Suez, Egypt. J Afr Earth Sci 156:133-143

Rouquerol J, Avnir D, Fairbridge CW, Everett DH (1994) Recommendations for the characterization of porous solids (Technical Report). Pure Appl Chem, 66

Shang FH, Zhu YM, Gao HT, Wang Y, Liu RY (2020) Relationship between tectonism and composition and pore characteristics of shale reservoirs. Geofluids 2020:14

Sing KSW (1982) Reporting physisorption data for gas/solid systems.

Tan JQ, Weniger P, Krooss B, Merkel A, Horsfield B, Zhang JC, Boreham CJ, van Graas G, Tocher BA (2014) Shale gas potential of the major marine shale formations in the Upper Yangtze Platform, South China, Part II: methane sorption capacity. Fuel 129:204-218

Wang X, Zhang L, Jiang C, Yin J, Gao C, Sun J, Yin N, Xue L (2018) The effect of differential uplift on pore development of Chang 7 shale in Ordos Basin: Case studies of Ganquan area and Weibei uplift area. Nat Gas Geosci 29:597-605

Wang Y, Liu LF, Cheng HF (2020) Pore structure of Triassic Yanchang mudstone, Ordos Basin: Insights into the impact of solvent extraction on porosity in lacustrine mudstone within the oil window. $\mathrm{J}$ Pet Sci Eng 195:11

Xu L, Wang Y, Liu L, Chen L, Chen J (2019a) Evolution characteristics and model of nanopore structure and adsorption capacity in organic-rich shale during artificial thermal maturation: a pyrolysis study of the Mesoproterozoic Xiamaling marine shale with type II kerogen from Zhangjiakou, Hebei China. Energy Explor Exploit $37: 493-518$

Xu LF, Zhang JC, Ding JH, Liu T, Shi G, Li XQ, Dang W, Cheng YS, Guo RB (2020) Pore structure and fractal characteristics of different shale lithofacies in the dalong formation in the Western Area of the Lower Yangtze platform. Minerals 10:25

Xu Y, Lu C, Chen G, Zhong J, Yang W, Xue L (2015) Fractal characteristics of shale pores of Longmaxi Formation in southeast Sichuan Basin. Lithologic Reservoirs 27:32-39

Xu ZY, Jiang S, Yao GS, Liang X, Xiong SY (2019b) Tectonic and depositional setting of the lower Cambrian and lower Silurian marine shales in the Yangtze Platform, South China: implications for shale gas exploration and production. J Asian Earth Sci 170:1-19

Yang C, Zhang J, Wang X, Tang X, Chen Y, Jiang L, Gong X (2017) Nanoscale pore structure and fractal characteristics of a marinecontinental transitional shale: a case study from the lower Permian Shanxi Shale in the southeastern Ordos Basin, China. Mar Pet Geol 88:54-68

Zhang K, Jia CZ, Song Y, Jiang S, Jiang ZX, Wen M, Huang YZ, Liu XX, Jiang T, Peng J, Wang X, Xia QS, Li B, Li X, Liu TL (2020a) Analysis of Lower Cambrian shale gas composition, source and accumulation pattern in different tectonic backgrounds: a case study of Weiyuan Block in the Upper Yangtze region and Xiuwu Basin in the Lower Yangtze region. Fuel 263:15

Zhang K, Peng J, Liu WW, Li B, Xia QS, Cheng SH, Yang YM, Zeng Y, Wen M, Liu DM, Huang YZ, Zhong L, Liu P, Jiang XJ (2020b) the role of deep geofluids in the enrichment of sedimentary organic matter: a case study of the late ordovician-early silurian in the upper yangtze region and early Cambrian in the Lower Yangtze Region. South China Geofluids 2020:12

Zhang K, Peng J, Wang X, Jiang ZX, Song Y, Jiang L, Jiang S, Xue ZX, Wen M, Li XH, Liu XX, Huang YZ, Wang PF, Shan CA, Liu TL, Xie XL (2020c) Effect of organic maturity on shale gas genesis and pores development: A case study on marine shale in the upper Yangtze region, South China. Open Geosci 12:1617-1629

Zhenhong C, Gu C, Song Y, Hongyan W (2007) Effects of tectonic uplift on physical properties of high and low rank coal reservoirs. Pet Explor Dev 34:461-464

Zou C, Dong D, Wang S, Li J, Li X, Wang Y, Li D, Cheng K (2010) Geological characteristics, formation mechanism and resource potential of shale gas in China. Pet Explor Dev 37:641-653

Zou C, Dong D, Wang Y, Li X, Huang J, Wang S, Guan Q, Zhang C, Wang H, Liu H, Bai W, Liang F, Lin W, Zhao Q, Liu D, Yang Z, Liang P, Sun S, Qiu Z (2016) Shale gas in China: characteristics, challenges and prospects (II). Petrol Explo Develop 43:182-196 